\title{
Are Shadow Economy and Corruption in US States Substitutive or Complementary? An Empirical Investigation'
}

Omer GOKCEKUS (https://orcid.org/0000-0001-8109-5918), School of Diplomacy and International Relations, Seton Hall University, United States of America; e-mail: omer.gokcekus@shu.edu

Friedrich SCHNEIDER (https://orcid.org/0000-0001-6742-5896), Reserach Institute for Banking and Finance, University of Linz, Austria; e-mail: friedrich.schneider@jku.at

\section{ABD'de Kayıt Dışı Ekonomi ve Yolsuzluk Birbirinin Yerine Mi Geçer Yoksa Birbirini Mi Tamamlar? Ampirik Bir Çalışma²}

\begin{abstract}
An empirical investigation of the 50 US States shows that the relationship between shadow economy and corruption is negative (substitutive) when the shadow economy is relatively small; it is positive (complementary) when the shadow economy is large. According to the robust regression results for 50 American states between 2001 and 2008, the turning point from negative to positive is when the shadow economy of a state is at 7.61 of its GDP. Shadow economy and corruption are first substitutive and then complementary. The lesson to learn is that there is no simple anti-corruption policy rule if one takes into account the varying interaction between corruption and the shadow economy.

Keywords : Shadow Economy, Corruption, USA.

JEL Classification Codes : $\quad$ C20, K42, P16.

$\ddot{\mathbf{O} z}$

$\mathrm{Bu}$ ampirik çalışma ABD'de kayıt dışı ekonominin küçük olduğu eyaletlerde kayıt dışı ekonomi ve yolsuzluk arasında negatif bir ilişkinin olduğunu (birbirinin yerine geçen); kayı1 dış1 ekonominin büyük olduğu eyaletlerde ise pozitif (birbirini tamamlayan) olduğunu göstermektedir. 2001-2008 yılları arasında, ABD'deki 50 eyalete ait verilere dayalı yapılan regresyon analiz sonuçlarına göre, bu ilişkinin negatiften pozitife geçtiği dönüm noktası, eyaletteki kayıt dış1 ekonominin GSYİH'nın \%7,61'i kadar olduğu yerdedir: Kayıt dışı ekonomi ve yolsuzluk önce birbirinin yerine geçmekte daha sonra ise birbirlerini tamamlamaktadırlar. Yolsuzluk ve kayıt dış1 ekonomi arasındaki ilişkinin değişken olduğunu göz önüne aldığımızda, yolsuzluğa karşı basit bir politika kuralı olamayacağı ortaya çıkmaktadır.
\end{abstract}

Anahtar Sözcükler $\quad$ : Kayıt Dıı̧ı Ekonomi, Yolsuzluk, ABD.

1 We would like to thank Adam Godet, Samin Gokcekus, Dennis Meaney, and Edward Tower for their helpful comments and suggestions.

2 Değerli katklarından ötürü Adam Godet, Samin Gokcekus, Dennis Meaney ve Edward Tower'a teşekkürü bir borç biliyoruz. 


\section{Introduction}

Corruption and the shadow economy have been in the focus of scientific interest for a long time. This interest is understandable because the extent of corruption and the size and development of a shadow economy are important indicators of bad governance; bad governance has negative effects on both economic efficiency and equity. In this paper we investigate how these two important indicators are related to one another in the 50 US States over the period 2001 to 2008 . Specifically, we focus on the interaction between corruption and shadow economy, as they may be complementary or substitutive to each other; meaning that someone either needs some extent of corruption to undertake shadow economy activities (and vice versa) or they can substitute corrupt activities with shadow economy activities.

This may have practical implications. For instance, it may be particularly important in deciding who gets a public contract: If I am the best and cheapest, I might get it in any case. If not, I then have two options, (1) I bribe the state official and I get it, (2) or I use shadow economy activities, hopefully be the cheapest, and get the contract. More importantly, knowing the nature of this relationship may help policy makers choose suitable policy instruments to effectively deal with corruption and the shadow economy.

To our knowledge this is the first investigation into this relationship in the 50 US States over the period $2001-2008$. To do so, in the following section 2 we provide a short literature review. In section 3 we make some theoretical considerations and formulate our key hypotheses. We econometrically test these hypotheses in section 4, in particular we investigate the direction and magnitude of the relationship between shadow economy and corruption; whether they are substitutive or complementary. Section 5 summarizes our main findings and provides policy recommendations that flow from our conclusions.

\section{A Short Literature Survey}

Four pieces of the literature are particularly relevant for our study. There are two standalone pieces examining corruption and shadow economy. Both are extensive, yet for brevity we are not reviewing them here ${ }^{3}$. We summarize the other two relevant pieces; 1) empirical studies focusing on corruption in the US, and 2) the relationship between shadow economy and corruption.

3 For a comprehensive literature survey on corruption, see, for instance, Bardahan (1997); Lambsdorff (2006); Treisman (2000); (2007). For shadow economy, see Schneider \& Enste (2000), Williams and Schneider (2016), and Schneider (2017). 


\subsection{Corruption in the US States}

The literature which focuses on corruption in the USA almost exclusively concentrates on federal corruption convictions to "explain" corruption (Bologna, 2017; Goel \& Nelson, 1998; Johnson \& LaFountain \& Yamarik, 2011; Leeson \& Sobel, 2008).

Goel \& Nelson, (1998) examines the effects of government size on corruption in 50 states between 1983 and 1987. They find a strong relationship between state governments' spending and federal corruption convictions. Glaeser \& Saks, (2006) investigate the causes and consequences of corruption over the period 1976 to 2002 in a cross-section analysis. The main finding of this study is that the more educated states and, to a smaller degree, the richer states are, the less federal corruption convictions are present, ceteris paribus. Johnson et al., (2011) investigates the relationship between corruption and growth and investment in 50 American states, 1975-2000. They conclude that corruption negatively affects both growth and investment. Finally, Bologna, (2017) shows that between 1997 and 2009, corruption is affecting competition positively in states with low levels of institutional quality and negatively, otherwise.

As is explained in these studies, corruption convictions can certainly be used as a proxy for corruption. Yet, they are only rough measures because they are dependent on the strength of anti-corruption laws and the enforcement of these laws in each one of the 50 American states. The disadvantage of this measure is that it cannot show us the total extent of corruption in an American state, it is on the other hand to some extent hard fact; it is not perception. It doesn't rely on survey evidence and these conviction levels capture the extent to which Federal prosecutors have charged and convicted public officials in each of the 50 states.

Moreover, Goel \& Nelson, (2011) in their paper "Measures of Corruption and Determinants of US Corruption" examine whether the conclusions from empirical models of corruption (which utilizes federal corruption convictions) are robust with respect to alternative measures of corruption used in US states. They come to a similar conclusion in Glaeser \& Saks (2006) that, regardless of the corruption measure used, the greater educational attainment there is, the lower the presence of corruption, ceteris paribus. They also find that the southern US states are among the more corrupt and additionally that greater judicial employment increases the presence of corruption, ceteris paribus. However, the influence of other important factors like urbanization, economic prosperity, population size, media, and government spending are sensitive to the measure of corruption.

\subsection{Shadow Economy-Corruption: Substitutive or Complementary?}

There are a limited number of studies, either theoretical or cross-country empirical, focusing on the relationship between corruption and shadow economy. According to RoseAckerman, (1998: 46), "In general, going 'underground' is a substitute for bribery, although in some cases firms bribe officials in order to avoid official status." She is saying that most of the times there is a negative relationship between corruption and shadow economy; i.e., 
they are substitutes of each other. Yet, sometimes, corruption takes place to enable or expand the shadow economy, i.e., they complement each other.

Choi \& Thum (2005) develop a self-selection model with heterogeneous entrepreneurs. They show that “... the entrepreneurs' option to flee to the underground economy constrains a corrupt official's ability to introduce distortions to the economy for private gains. The unofficial economy thus mitigates government-induced distortions and, as a result, leads to enhanced economic activities in the official sector. In this sense, the presence of the unofficial sector acts as a complement to the official economy instead of as a substitute." Dreher, Kotsogiannis, \& McCorriston (2009) extends Choi \& Thum (2005) by explicitly specifying the quality of institutions. They show that shadow economy and corruption are substitutes.

On the contrary Johnson, Kaufmann, \& Shleifer (1997) argue theoretically, and also provide empirical evidence, that in the economies of eastern Europe and the former Soviet Union corruption increases the shadow economy, as corruption leads to particular forms of taxation and regulation, that drive entrepreneurs underground. Thus, corruption and shadow economy are complementary. Hibbs \& Piculescu (2005) derive the same conclusion. They explain both theoretically and empirically that corrupt bureaucrats overlook shadow production in exchange for bribes; corruption increases the size of the shadow economy.

All in all, from these studies, we conclude that the debate about the relationship between the shadow economy and corruption is thus unsettled. Due to this we cannot formulate a clear-cut hypothesis about the relationship between the shadow economy and corruption. Accordingly, in our model we leave the sign open; it can be positive or negative.

\section{Model, Variables, Data}

To answer our research question, to empirically check the sign and magnitude of the relationship between corruption and shadow economy, it is not easy to come up with a clearcut theoretical model. As Goel \& Nelson (2011: 159) argued by referring to Alt \& Lassen (2003: 342), “... there is no commonly agreed upon theoretical approach on which to base an empirical model of corruption..." Accordingly, to examine the possible relationship between corruption and the size of the shadow economy of a state, we estimate the following model $^{4}$ :

$$
\begin{aligned}
& \text { Corruption }_{i t}=\beta_{0}+\beta_{1} \text { Shadow economy }_{i t}+\beta_{2}(\text { Shadow economy } \\
& \left.\sum_{j=3}^{k} \beta_{j}\right)^{2}+
\end{aligned}
$$


Corruption is the ratio of the number of federal corruption convictions to GDP in constant 2009 dollars; i stands for state i, i=Alabama, Alaska, ..., Wyoming; and t stands for a two year election cycle between 2001 and 2008, $t=2001-2002,2003-2004, \ldots, 2007$ 2008. $(2013)^{5}$.

The size of the shadow economy is expressed as a percent of GDP as from Wiseman

As we discussed in the previous section, we do not have a priori expectation regarding the sign of the relationship between shadow economy and corruption. Therefore, not to impose either positive or negative relationship between corruption and shadow economy, and also to allow a change in its sign depending on the level of shadow economy, we included both shadow economy and (shadow economy) ${ }^{2}$ as explanatory variables in the right-hand side of the equation. According to this formulation, for instance, if

$$
\begin{aligned}
& \beta_{1}>0 \text { and } \beta_{2}=0 \text {, or } \beta_{1}>0 \text { and } \beta_{2}>0 \text { : complementary } \\
& \beta_{1}<0 \text { and } \beta_{2}=0 \text {, or } \beta_{1}<0 \text { and } \beta_{2}<0: \text { substitutive } \\
& \beta_{1}>0 \text { and } \beta_{2}<0: \text { substitutive and then complementary }
\end{aligned}
$$

If $\beta_{1} \neq 0$ and $\beta_{2} \neq 0$, the turning point for the relationship between shadow economy and corruption from substitute to complementary, or vice versa will be the following:

$$
\text { shadow economy } y_{\text {turning point }}=-\frac{\beta_{1}}{2 \beta_{2}}
$$

We use three sets of control variables to capture the effects of different demographic and geographical characteristics in each state, we included additional relevant variables, i.e., $X_{j} \mathrm{~s}$, in the right-hand side of the equation. In determining additional explanatory relevant variables, i.e., control variables, we count on Glaser \& Saks (2006)-income and education; Mauro (1995) and Treisman (2007)-ethnic heterogeneity; and Glaser \& Saks (2006) and Gokcekus \& Sonan, (2017)-government regulations and enforcement of these regulations; and Goel \& Nelson (2011) and Glaser \& Saks (2006)-regional differences.

5 Wiseman (2013) follows the macro approach in Buehn \& Schneider (2012) and estimates the size of the shadow economy using the multiple indicators multiple causes (MIMIC) method for each US state. Wiseman (2013), which is to our knowledge is the only study measuring the size of the shadow economy of all 50 US. Wiseman's results suggest that tax and social welfare burdens, labour market regulations are important determinants of the size and development of the 50 US states shadow economies. There are other macro approaches to estimate the size of the shadow economy such as the currency demand approach, e.g., see Ardizzi, Petraglia, Piacenza, \& Turati (2014) as well as micro approaches, for instance, see Ekici \& Besim (2016). 
In particular, to capture demographic variations, we included 1) the level of income in state $\mathrm{i}$ at time $\mathrm{t}, \ln$ (GDP per capita income), in constant 2009 dollars; 2) the racial composition, Black \% of the population; 3) the age composition, Age (65+) \%; and 4) educational attainment, College \%; 5) regional differences, we included Midwest, Northeast, and $\mathrm{West}^{6}$. To capture 6) strength of law enforcement by courts in general and specifically 7) strength of anti-corruption laws in each state, we included, Stringent anti-corruption laws and Total Federal convictions (per 100,000) ${ }^{7}$. Finally, we added $\mathrm{v}$ as a well-behaving random error term.

Table: 1

\section{Summary Statistics and Data Sources (For 4 Election Cycles between 2001 and 2008)}

\begin{tabular}{|l|c|c|c|c|l|}
\hline Variable & Mean & Std. Dev. & Min. & Max. & Source \\
\hline $\begin{array}{l}\text { Federal corruption convictions/ } \\
\text { Real GDP }\end{array}$ & 78.51 & 61.15 & 0.00 & 404.47 & U.S. Department of Justice, Public Integrity Section \\
\hline & & & & & \\
\hline $\begin{array}{l}\text { Shadow economy } \\
\text { (\% of state GDP) }\end{array}$ & 8.02 & 0.79 & 6.14 & 9.99 & Wiseman (2013) \\
\hline & & & & & \\
\hline $\begin{array}{l}\text { Real GDP } \\
\text { (in constant 2009 million dollars) }\end{array}$ & $\$ 276,101$ & $\$ 327,684$ & $\$ 23,159$ & $\$ 1,999,596$ & $\begin{array}{l}\text { U.S. Department of } \\
\text { Commerce, Bureau of } \\
\text { Economic Analyses }\end{array}$ \\
\hline & & & & & \\
\hline Black \% & 9.84 & 9.42 & 0.00 & 37.00 & U.S. Department of Commerce, Census Bureau \\
\hline Female \% & 48.86 & 0.75 & 48.00 & 50.00 & U.S. Department of Commerce, Census Bureau \\
\hline Age (19-64) \% & 60.94 & 1.55 & 57.00 & 65.00 & U.S. Department of Commerce, Census Bureau \\
\hline College grad. \% & 27.49 & 4.78 & 17.50 & 39.00 & U.S. Department of Commerce, Census Bureau \\
\hline $\begin{array}{l}\text { Total Federal convictions } \\
\text { (Per 100,000) }\end{array}$ & 25.18 & 19.1 & 7.66 & 139.12 & U.S. Department of Commerce, Bureau of Justice Statistics \\
\hline & & & & & \\
\hline Stringent anti-corruption laws & 1.60 & 1.27 & 0.00 & 5.00 & Center of Public Integrity \\
\hline
\end{tabular}

Table 1 provides summary statistics for four election cycles, between 2001 and 2008. As summarized in column 1, in the US during the 2001-2008 period, the average size of the shadow economy was $8.0 \%$ of GDP; and it was taking values between $6.1 \%$ (Oregon, 20072008 election cycle) and 10.0\% (Mississippi, 2001-2002 election cycle. The average federal convictions per real GDP was 78.5; and it was taking values between 0.0 (Wyoming, 2001 2002 election cycle) and 404.7 (North Dakota, 2003-2004 election cycle). Figure 1 is the

6 The default region is South-Alabama, Arkansas, Delaware, Florida, Georgia, Kentucky, Louisiana, Maryland, Mississippi, North Carolina, Oklahoma, South Carolina, Tennessee, Texas, Virginia, and West Virginia. Midwest-Illinois, Indiana, Iowa, Kansas, Michigan, Minnesota, Missouri, Nebraska, North Dakota, Ohio, South Dakota, and Wisconsin; Northeast -- Connecticut, Maine, Massachusetts, New Hampshire, New Jersey, New York, Pennsylvania, Rhode Island, Vermont; and West - Alaska, Arizona, California, Colorado, Hawaii, Idaho, Montana, New Mexico, Oregon, Utah, Nevada, Washington, Wyoming. These are regional divisions used by the US Census Bureau.

7 To obtain Federal Convictions figures, we used the Federal Criminal Case Processing Statistics provided by Bureau of Justice Statistics, which complies data on the federal criminal justice system. To be more precise, we used the number of "offenders sentenced" by states, classified under prosecution/courts. We used the State Integrity Investigation 2015 to measure the effectiveness of each states' laws and systems in deterring corruption, which is compiled by the Center for Public Integrity in partnership with Global Integrity. 
scatter chart showing the relationship between corruption and shadow economy in 50 states in the 2001-2008 period.

\section{Figure: 1}

\section{Shadow Economy versus Corruption}

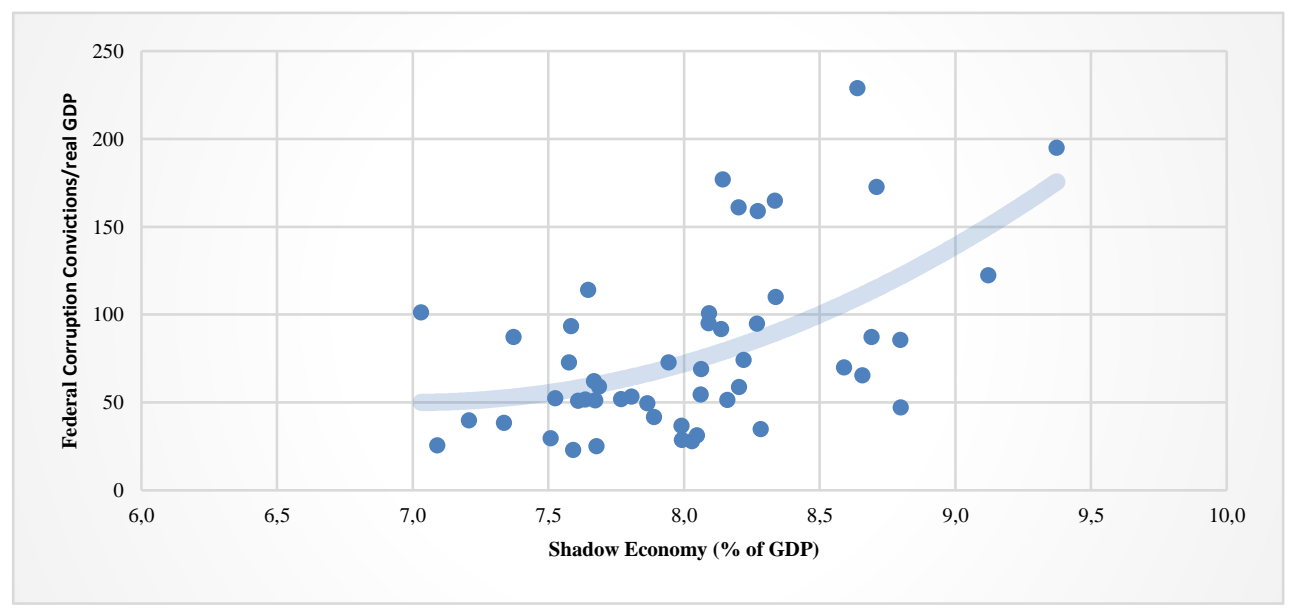

\section{Empirical Results}

Having 50 states in our sample for four election cycles we run four sets of robust regressions by utilizing the panel data with 200 observations.

First, robust regression results for the bare minimum version of the model in Equation 1 , with just Shadow and Shadow ${ }^{2}$ on the right-hand side, as a benchmark is presented in Table 2 column $(1)$ : The estimates are $-205.4(\mathrm{P}<0.05)$ and $13.9(\mathrm{P}<0.05)$ for Shadow and Shadow $^{2}$ variables, respectively. That is to say, (1) the relationship between shadow economy and corruption is negative first, and then positive; and (2) the turning point from negative to positive is at shadow economy $=7.36$.

Second, we estimate the model with only regional dummies included. According to the results presented in column (2), for Shadow and Shadow ${ }^{2}$ variables, the estimates are $192.9(\mathrm{P}<0.05)$ and $12.9(\mathrm{P}<0.05)$, respectively. Accordingly, the relationship between shadow economy and corruption is negative when the shadow economy is small; up to shadow economy $=7.46$, and then positive. Moreover, compared to the South, corruption is lower in the other regions, ceteris paribus; the estimated coefficient for the West is $-39.5(\mathrm{P}$ $<0.01)$, Northeast $-35.0(\mathrm{P}<0.01)$, and Midwest $-23.3(\mathrm{P}<0.05)$.

Third, we estimate the model with regional dummies, stringent anti-corruption laws and total federal corruption convictions (per 100,000). The estimation results are presented in Column (3). The estimates are $-200.4(\mathrm{P}<0.05)$ and $13.3(\mathrm{P}<0.05)$ for Shadow and Shadow $^{2}$ variables, respectively. That is to say, for the relationship between shadow 
economy and corruption, the turning point from negative to positive is at shadow economy $=7.52$. Compared to the South, corruption is lower in the other regions, ceteris paribus; the estimated coefficient for the West is $-46.2(\mathrm{P}<0.01)$, Northeast $-32.9(\mathrm{P}<0.01)$, and Midwest $-23.1(\mathrm{P}<0.05)$. The estimated coefficient for total federal convictions (per $100,000)$ is $0.37(\mathrm{P}<0.10)$, which implies that federal courts making more conviction decisions are also producing more corruption convictions.

Table: 2

\section{Robust Regression Results: Dependent Variable-Federal Corruption Convictions/Real GDP}

\begin{tabular}{|c|c|c|c|c|}
\hline & (1) & (2) & (3) & (4) \\
\hline \multirow[t]{2}{*}{ Constant } & 820.183 & 808.60 & 829.316 & 743.521 \\
\hline & $(393.16)^{* * *}$ & $(372.42)^{* * *}$ & $(376.14)^{* * *}$ & $(402.38)^{* * *}$ \\
\hline \multirow{2}{*}{ Shadow } & -205.410 & -192.891 & -200.356 & -182.346 \\
\hline & $(100.81)^{* *}$ & $(96.29)^{* * *}$ & $(97.76)^{* *}$ & $(96.41)^{* * *}$ \\
\hline \multirow[t]{2}{*}{$(\text { Shadow })^{2}$} & 13.946 & 12.920 & 13.328 & 11.985 \\
\hline & $(6.43)^{* * *}$ & $(6.17)^{* * *}$ & $(6.28)^{* *}$ & $(6.24)^{* *}$ \\
\hline \multirow{2}{*}{ West } & & -39.531 & -46.179 & -28.878 \\
\hline & & $(10.77)^{* * * *}$ & $(10.68)^{* * * *}$ & $(15.30)^{* * *}$ \\
\hline \multirow{2}{*}{ Northeast } & & -34.983 & -32.868 & -7.638 \\
\hline & & $(9.37)^{* * * *}$ & $(9.89)^{* * *}$ & (14.86) \\
\hline \multirow{2}{*}{ Midwest } & & -23.276 & -23.105 & -10.244 \\
\hline & & $(13.06)^{* * *}$ & $(13.13)^{* *}$ & (13.18) \\
\hline \multirow{2}{*}{ Total federal convictions (per 100,000 ) } & & & 0.366 & 0.351 \\
\hline & & & $(0.23)^{*}$ & $(0.23)^{*}$ \\
\hline \multirow{2}{*}{ Stringent anti-corruption enforcement } & & & 2.947 & 5.081 \\
\hline & & & $(3.23)$ & $\frac{5.001}{(3.51)^{*}}$ \\
\hline \multirow[t]{2}{*}{ Black \% } & & & & 0.555 \\
\hline & & & & $(0.78)$ \\
\hline \multirow{2}{*}{ Age $19-64 \%$} & & & & 1.424 \\
\hline & & & & $(2.96)$ \\
\hline \multirow{2}{*}{ College graduate $\%$} & & & & -2.708 \\
\hline & & & & $(1.24) * * *$ \\
\hline \multirow{2}{*}{ Per capita income } & & & & -0.096 \\
\hline & & & & $(0.76)$ \\
\hline No. of Obs. & 200 & 200 & 200 & 200 \\
\hline $\mathrm{R}^{2}$ & 0.08 & 0.15 & 0.16 & 0.19 \\
\hline F-statistic & $4.96^{* * * *}$ & $6.16^{* * * *}$ & $5.34 * * *$ & $3.98 * * *$ \\
\hline
\end{tabular}

Standard errors are reported in parentheses.

Significance level: $*=P<0.10, * *=P<0.05, * * *=P<0.01$.

Fourth, finally, we estimate our full model; we add demographic characteristics. As is presented in Column (4) of Table 2, four main results emerge: (1) for Shadow and Shadow $^{2}$ variables, the estimates are $-182.3(\mathrm{P}<0.05)$ and $12.0(\mathrm{P}<0.05)$, respectively. Accordingly, the relationship between shadow economy and corruption is negative when shadow economy is small; up to shadow economy $=7.61$, and then positive. (2) Compared to the South, corruption is lower in the West region, ceteris paribus; the estimated coefficient for the West is $-28.9(\mathrm{P}<0.05)$. (3) The estimated coefficient for total federal convictions (per 100,000) is $0.35(\mathrm{P}<0.10)$, which implies that federal courts making more conviction decisions are also producing more corruption convictions; the estimated coefficient for stringent anti-corruption enforcement is $5.1(\mathrm{P}<0.10)$, which implies that having stringent anti-corruption laws results in more corruption convictions. (4) Among demographic 
variables only College graduate $\%$ has a statistically significant effect on corruption: for College graduate $\%$, the estimate is $-2.7(\mathrm{P}<0.01)$.

\subsection{Robustness Check}

To acknowledge that causality between corruption and shadow economy might be in both directions, we utilize the following simultaneous equations model:

$$
\begin{aligned}
& \text { Corruption }_{i t}=\beta_{0}+\beta_{1} \text { Shadow economy }_{i t}+\beta_{2}(\text { Shadow economy } \\
& \left.\sum_{j=3}^{k} \beta_{j}\right)^{2}+
\end{aligned}
$$

Shadow economy $_{i t}=\delta_{0}+\delta_{1}$ Corruption $_{i t}+\sum_{j=2}^{k} \delta_{j} X_{j}+\varepsilon_{i t}$

Table: 3

\begin{tabular}{|c|c|c|}
\hline & Shadow & Federal Corruption Convictions/Real GDP \\
\hline \multirow{2}{*}{ Constant } & 8.794 & 657.025 \\
\hline & $(2.09)^{* * * *}$ & $(380.67)^{* * *}$ \\
\hline \multirow{2}{*}{ Federal Corruption Convictions/Real GDP } & 0.002 & \\
\hline & $(0.001)^{* * * *}$ & \\
\hline \multirow{2}{*}{ Shadow } & & -170.758 \\
\hline & & $(83.74)^{* *}$ \\
\hline \multirow[t]{2}{*}{$(\text { Shadow })^{2}$} & & 11.770 \\
\hline & & $(5.24) * * * *$ \\
\hline \multirow{2}{*}{ West } & 0.040 & -28.692 \\
\hline & $(0.19)$ & $(16.39)^{* * *}$ \\
\hline \multirow{2}{*}{ Northeast } & 0.205 & -9.208 \\
\hline & $(0.20)$ & (17.17) \\
\hline \multirow{2}{*}{ Midwest } & 0.004 & -10.091 \\
\hline & $(0.16)$ & (14.19) \\
\hline \multirow{2}{*}{ Total federal convictions (per 100,000) } & 0.003 & 0.320 \\
\hline & $(0.003)$ & $(0.24)^{*}$ \\
\hline \multirow{2}{*}{ Stringent anti-corruption enforcement } & 0.054 & 4.540 \\
\hline & $(0.04) *$ & $(3.42)^{*}$ \\
\hline \multirow[t]{2}{*}{ Black \% } & 0.005 & 0.504 \\
\hline & $(0.01)$ & $(0.66)$ \\
\hline \multirow[b]{2}{*}{ Age $19-64 \%$} & 0.022 & 1.214 \\
\hline & $(0.03)$ & $(3.03)$ \\
\hline \multirow{2}{*}{ College graduate $\%$} & 0.004 & -2.695 \\
\hline & $(0.01)$ & $(1.19) * * *$ \\
\hline \multirow{2}{*}{ Per capita income } & -0.059 & 0.395 \\
\hline & $(0.01)^{* * * *}$ & $(0.73)$ \\
\hline No. of Obs. & \multicolumn{2}{|l|}{$(0.01)$} \\
\hline $\mathrm{R}^{2}$ & 0.36 & 0.18 \\
\hline$\chi^{2}$ & 118.19 & $51.95^{* * *}$ \\
\hline
\end{tabular}

\section{Seemingly Unrelated Regression Estimation Results}

Standard errors are reported in parentheses.

Significance level: $*=P<0.10, * *=P<0.05, * * *=P<0.01$.

Table 3 summarizes the seemingly unrelated regression estimation results ${ }^{8}$. According to the results reported in column (2), for Shadow and Shadow ${ }^{2}$ variables, the estimates are $-170.8(\mathrm{P}<0.05)$ and $11.8(\mathrm{P}<0.01)$, respectively. As is in the previous 
estimations, the relationship between shadow economy and corruption is negative when shadow economy is small; up to shadow economy $=7.25$, and then positive. Compared to the South, corruption is lower in the West region, ceteris paribus; the estimated coefficient for the West is $-28.7(\mathrm{P}<0.05)$. The estimated coefficient for total federal convictions (per $100,000)$ is 0.32 ( $\mathrm{P}<0.10)$, which implies that federal courts making more conviction decisions are also producing more corruption convictions; the estimated coefficient for stringent anti-corruption enforcement is $4.5(\mathrm{P}<0.10)$, which implies that having stringent anti-corruption laws results in more corruption convictions. Among demographic variables only College graduate $\%$ has a statistically significant effect on corruption: for College graduate $\%$, the estimate is $-2.7(\mathrm{P}<0.01)^{9}$.

\section{Figure: 2}

\section{Turning Point for the Relationship between Shadow Economy and Corruption}

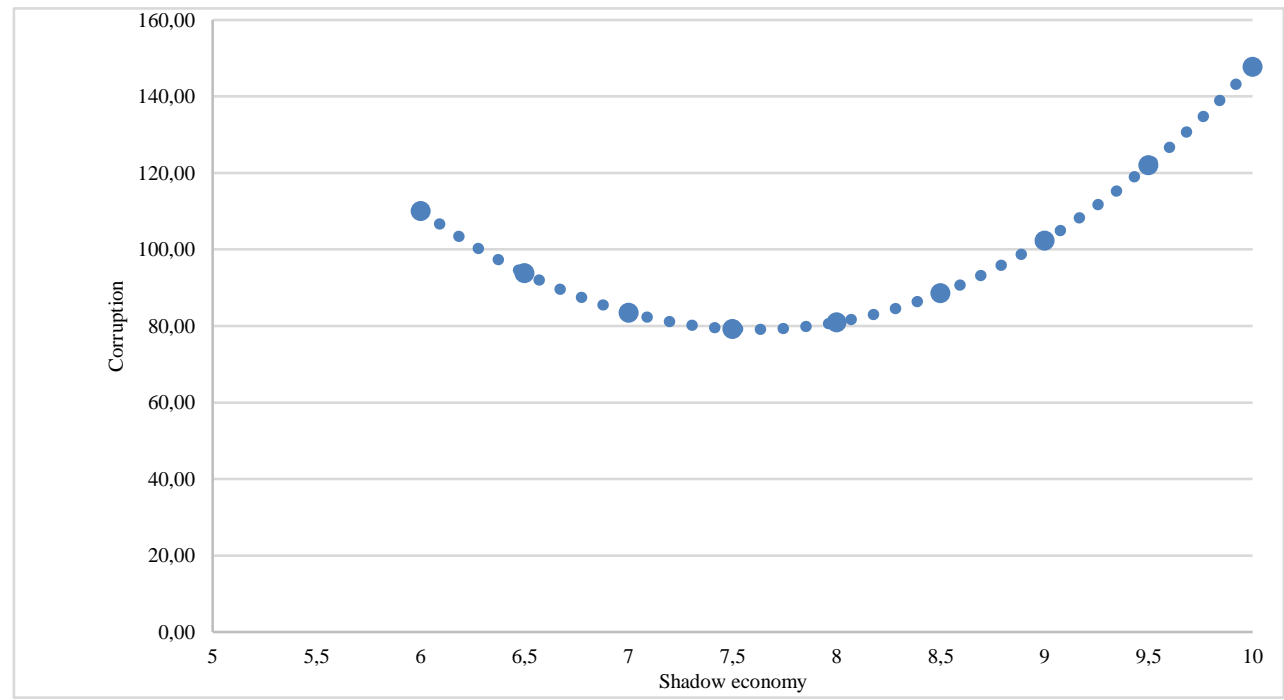

19 states on the LHS of the turning point at shadow economy $=7.61$

States with shadow economy scores $<7.61$

Alaska, California, Colorado, Connecticut, Delaware, Georgia, Illinois, Massachusetts, Minnesota, Nevada, New Hampshire, New Jersey, New York, North Carolina, Ohio, Oregon, Texas, Wisconsin, Wyoming
31 states on the RHS of the turning point at shadow economy $=7.61$

States with shadow economy scores > 7.61

Alabama, Arizona, Arkansas, Florida, Hawaii, Idaho, Indiana, Iowa, Kansas, Kentucky, Louisiana, Maine, Maryland, Michigan, Mississippi, Missouri, Montana, Nebraska, New Mexico, North Dakota, Oklahoma, Pennsylvania, Rhode Island, South Carolina, South Dakota, Tennessee,

Utah, Vermont, Virginia, Washington, West Virginia

9 We have also estimated the model in Equation 1 with both fixed and random effects specifications. The model with these two specifications were not statistically significant. Therefore, we are not reporting and discussing the estimation results from these two models. 


\subsection{Substitutive or Complementary?}

To recap, the relationship between shadow economy and corruption is negative when the shadow economy is small; and it is positive when the shadow economy is large. For instance, according to the robust regression results of the complete model, presented in Table 2, column (4), the turning point is 7.61. Figure 2 depicts this relationship. Thus, for the 19 states with a shadow economy smaller than 7.61 percent of their GDP, the relationship was negative for years 2005 and 2006; and positive for the remaining 31 states ${ }^{10}$. The states are listed at the bottom of Figure 2.

\section{Concluding Remarks}

In this study we empirically investigated the relationship between corruption and the shadow economy in the 50 US States over the period 2001 to 2008, for the first time. Our main results are the following:

- Corruption is significantly lower in the states in the West region compared to the states in the South region, ceteris paribus: The estimated coefficient for the West variable is $-28.9(\mathrm{P}<0.05)$.

- Among the demographic variables, only the variable College graduate (\%) has a statistically significant, negative influence on corruption; the estimated coefficient is $-2.72(\mathrm{P}<0.01)$.

- Stringent anti-corruption laws and how frequently federal courts make conviction decisions also effect the federal corruption convictions/real GDP; However, the estimated coefficients of these two variables, 0.35 and 5.08 are only statistically significant at the 10 percent level $(\mathrm{P}<0.10)$.

- The estimated coefficients for Shadow and Shadow ${ }^{2}$ variables are $-182.34(\mathrm{P}<$ $0.05)$ and $11.98(\mathrm{P}<0.05)$ : The relationship between corruption and the shadow economy is negative, when the shadow economy is relatively small; and is positive when the shadow economy is relatively large. According to our robust regression results for the 50 US States, the turning point from negative to positive is when the shadow economy reaches a size of $7.61 \%$ of its GDP. This means corruption and the shadow economy are first substitutive and then complementary.

What lessons can we derive from these results, particularly from the fourth one? (i) There is no simple anti-corruption policy rule if one takes into consideration corruption's interaction with the shadow economy. It depends on whether we have a substitutive or complementary case. Therefore, we suggest that rather than looking for silver bullets to hit both corruption and the shadow economy, policy makers should keep focusing on the

10 The turning point varies depending on the specification of the model; yet in a relatively narrow range of 7.25 7.61 . 
fundamentals: (ii) Good governance policy rules and measures to reduce both evils (corruption and the shadow economy) are necessary to cope with both; and (iii) Well-trained and educated staff in public service are needed; as well as (iv) Better paid civil servants and severe punishment, when detected, so that the incentive, to take bribes is reduced.

\section{References}

Alt, J.E. \& D.D. Lassen (2003), "The political economy of institutions and corruption in American states", Journal of Theoretical Politics, 15(3), 341-365.

Ardizzi, G. \& C. Petraglia \& M. Piacenza \& G. Turati (2014), "Measuring the underground economy with the currency demand approach: A reinterpretation of the methodology, with an application to Italy", Review of Income and Wealth, 60(4), 747-772.

Bardahan, P. (1997), "Corruption and development: A review of issues”, Journal of Economic Literature, 35(3), 1320-1346.

Bologna, J. (2017), “Corruption, Product Market Competition, and Institutional Quality: Empirical Evidence From the U.S. States", Economic Inquiry, 55(1), 137-159.

Buehn, A. \& F. Schneider (2012), "Shadow economies around the world: Novel insights, accepted knowledge, and new estimates", International Tax and Public Finance, 19(1), 139-171.

Choi, J.P. \& M. Thum (2005), "Corruption and the Shadow Economy", International Economic Review, 46(3), 817-836.

Dreher, A. \& F. Schneider (2010), "Corruption and the shadow economy: an empirical analysis", Public Choice, 144(1-2), 215-238.

Dreher, A. \& C. Kotsogiannis \& S. McCorriston (2009), "How do institutions affect corruption and the shadow economy?", International Tax and Public Finance, 16(6), 773-796.

Ekici, T. \& M. Besim (2016), “A Measure of the Shadow Economy in a Small Economy: Evidence from Household-Level Expenditure Patterns", Review of Income and Wealth, 62(1), 145160.

Glaeser, E.L. \& R.E. Saks (2006), "Corruption in America”, Journal of Public Economics, 90(6-7), 1053-1072.

Goel, R.K. \& M.A. Nelson (1998), “Corruption and Government Size: A Disaggregated Analysis”, Public Choice, 97(1), 107-20.

Goel, R.K. \& M.A. Nelson (2011), "Measures of corruption and determinants of US corruption", Economics of Governance, 12(2), 155-176.

Gokcekus, O. \& S. Sonan (2017), "Political contributions and corruption in the United States", Journal of Economic Policy Reform, 20(4), 360-372.

Hibbs Jr., D.A. \& V. Piculescu (2005), “Tax Toleration and Tax Evasion: Why Firms Enter the Unofficial Economy”, CEFOS Working Paper 1.

Johnson, N.D. \& C.L. LaFountain \& S. Yamarik (2011), "Corruption is bad for growth (even in the United States)", Public Choice, 147(3-4), 377-393.

Johnson, S. \& D. Kaufmann \& A. Shleifer (1997), The Unoffficial Economy in Transition (Vol. 2). Brookings Papers on Economic Activity.

Lambsdorff, J. (2006), "Causes and Consequences of Corruption: What Do We Know from a Crosssection of Countries?", in: S. Rose-Ackerman (ed.), International Handbook on the Economics of Corruption, Cheltenham: Edward Elgar, 3-51. 
Leeson, P.T. \& R.S. Sobel (2008), "Weathering Corruption”, The Journal of Law and Economics, 51(4), 667-681.

Mauro, P. (1995), “Corruption and growth”, Quarterly Journal of Economics, 110, 681-712.

Rose-Ackerman, S. (1998), “Corruption and Development”, in: B. Pleskovic \& J.E. Stiglitz (eds.), World Bank Conference on Economic Development 1997, 35-57.

Schneider, F. (2017), "Estimating a Shadow Economy: Results, Methods, Problems, and Open Questions", Open Economics, 2017/1, 1-29.

Schneider, F. \& D.K. Enste (2000), "Shadow Economies: Size, Causes, and Consequences", Journal of Economic Literature, 64(March 1994), 1332-1334.

Treisman, D. (2000), "The causes of corruption: a cross-national study", Journal of Public Economics, 76, 399-457.

Treisman, D. (2007), "What have we learned about the causes of corruption from ten years of crossnational empirical research?", Annual Review of Political Science, 10, 211-244.

Williams, C.C. \& F. Schneider (2016), Measuring the Global Shadow Economy, Cheltenham (UK): Edward Elgar Publishing Company.

Wiseman, T. (2013), “US shadow economies: A state-level study", Constitutional Political Economy, 24(4), 310-335.

Zellner, A. (1962), "An efficient method of estimating seemingly unrelated regressions and tests for aggregation bias”, Journal of the American Statistical Association, 57, 348-368. 
Gokcekus, O. \& F. Schneider (2020), "Are Shadow Economy and Corruption in US States Substitutive or Complementary? An Empirical Investigation”, Sosyoekonomi, Vol. 28(46), 11-23. 